\title{
Analysis of meteorological droughts in the Sonora river basin, Mexico
}

\author{
Claudio César HERNÁNDEZ VÁSQUEZ ${ }^{1}$, Laura Alicia IBÁÑEZ CASTILLO²*, \\ Jesús David GÓMEZ DÍAZ ${ }^{3}$ and Ramón ARTEAGA RAMÍREZ ${ }^{2}$
}

\author{
${ }^{1}$ Doctorado en Ingeniería Agrícola y Uso Integral del Agua, Universidad Autónoma Chapingo, km. 38.5 carretera \\ México-Texcoco, 56230, Chapingo, Estado de México, México. \\ ${ }^{2}$ Departamento de Irrigación, Universidad Autónoma Chapingo, km. 38.5 carretera México-Texcoco, 56230, Chapingo, \\ Estado de México, México. \\ ${ }^{3}$ Departamento de Suelos, Universidad Autónoma Chapingo, km. 38.5 carretera México-Texcoco, 56230, Chapingo, \\ Estado de México, México. \\ *Corresponding author: libacas@gmail.com
}

Received: July 31, 2020; accepted: December 11, 2020

\begin{abstract}
RESUMEN
La sequía es un peligro natural complejo que tiene numerosos efectos negativos en los ecosistemas, la agricultura y la economía. Por esta razón, es difícil dar una definición precisa. Sin embargo, diferentes conceptualizaciones convergen en un denominador común: el déficit de precipitación con respecto a un valor histórico promedio. Las sequías en México han sido recurrentes y persistentes, como resultado de complejas interacciones de la atmósfera con los océanos y las características geográficas y fisiográficas del país. Varios investigadores han abordado este fenómeno utilizando índices para caracterizarlo, considerando características como la intensidad, la duración y la frecuencia. En este estudio analizamos las sequías en un contexto espacio-temporal a escalas de 3, 6, 12 y 24 meses con los índices SPI y SPEI en 19 estaciones meteorológicas ubicadas en las regiones media y alta de la cuenca del río Sonora, México, para el período 1974 -2013. Las regiones se definieron de acuerdo con el comportamiento de la precipitación media anual, aplicando técnicas estadísticas y analizando las características fisiográficas de la región de estudio. Los resultados indican que la intensidad de la sequía aumentó al final de la serie temporal analizada, y se identificaron períodos importantes en los años 1997, 1999, 2000 y 2011 a 2013. El SPEI definió los períodos de sequía y la tendencia creciente de la intensidad mejor que el SPI, lo que demuestra la importancia de incluir variables como la evapotranspiración en el balance de agua disponible.
\end{abstract}

\begin{abstract}
Drought is a complex natural hazard that has numerous negative effects on ecosystems, agriculture, and the economy. For this reason, it is difficult to provide a precise definition. Nevertheless, different conceptualizations converge in one common denominator: the deficit of precipitation with respect to an average historical value. Droughts in Mexico have been recurrent and persistent, resulting from complex interactions of the atmosphere with the oceans and the geographic and physiographic characteristic of the country. Several researchers have approached this phenomenon with indices to characterize it using features such as intensity, duration and frequency. In this study we analyze droughts in a spatiotemporal context at scales of 3, 6, 12 and 24 months with SPI and SPEI indices at 19 weather stations located in middle and upper regions of the Sonora River basin, Mexico, for the period 1974-2013. The regions were defined according to mean annual rainfall behavior, applying statistical techniques and analyzing the physiographic characteristics of the study region. Results indicate that drought intensity increased at the end of the time series analyzed, and important periods were identified in the years 1997, 1999, 2000 and 2011 to 2013. SPEI defined the drought periods and the increasing intensity trend better than SPI, demonstrating the importance of including variables such as evapotranspiration in the balance of available water.
\end{abstract}

Keywords: SPI, SPEI, principal components analysis, regionalization of precipitation. 


\section{Introduction}

Droughts were defined in the United Nations Convention to Combat Desertification (UNCCD, 1994) as a phenomenon that is produced naturally when rainfall is considerably lower than the normal recorded levels and, because of its extraordinary characteristic, has considerable impact at the ecological, economic and social levels. Climate change is producing higher temperatures, lower precipitation, and more droughts with higher intensity and duration (Castillo-Castillo et al., 2017)

Wilhite and Glantz (1985) established four types of droughts: meteorological, agricultural, hydrological and socioeconomic. The first three measure drought as a physical phenomenon, while the fourth sees it as a balance of supply and demand. These operational definitions that attempt to give objective criteria of specific applicability (Zargar et al., 2011) were favorably received by the World Meteorological Organization (Ponvert-Delisles and Dámaso, 2016) as well as by Esquivel-Arriaga et al. (2019), Khatiwada and Pandey (2019), Paredes et al.(2014) and Spinoni et al. (2019). Burton et al. (1993) defined seven parameters to characterize droughts: one independent (intensity), four referring to the temporal component (duration, frequency, rate of implantation and temporal spacing), and two referring to the spatial component (extension and dispersion). These parameters can be analyzed using indices to express impact numerically (Valiente, 2001; Zarch et al., 2011). The World Meteorological Organization (OMM and Asociación Mundial para el Agua, 2016) in their manual of drought indicators and indices, describes the 50 most-used indices worldwide and point out that none can be attributed or applied to all types of drought, climate regimes or affected sectors. For this reason, to analyze droughts, it is convenient to consider more than one index with the goal of examining the sensitivity and precision of each one (Ortiz-Gómez et al., 2018).

Numerous indices have been developed in recent years to identify characteristic of meteorological droughts. The most used is SPI (Standardized Precipitation Index) proposed by McKee et al. (1993). To calculate this index, monthly historical registers of precipitation are used to establish a probability of occurrence with positive and negative values that correlate directly with episodes of humidity and drought.
Only precipitation data are considered and not temperature, which is important for the water balance when processes of atmospheric warming are included and offers a panorama of evaporative demand. For this reason, Vicente-Serrano et al. (2010) proposed SPEI (Standardized Precipitation Evapotranspiration Index), which includes in its calculation a monthly climate water balance using the difference between precipitation and evapotranspiration as entry data. Both indices enable identification of conditions of deficit and excess humidity at different temporal scales. The corresponding values at a period of three month or less can be useful for basic drought monitoring, values for a period of 6 months or less to monitor effects on agriculture and values for a period of 12 months or more for hydrological effects (SMN, 2019).

Mishra and Singh (2010) mention that in recent years droughts have had higher peaks and severity levels superior to those registered in the past century, as well as shorter intervals of occurrence, signaling climate change. Droughts are insidious natural hazards that pose serious challenges, and their study, identification, and monitoring of their main characteristics have become integral parts of planning, preparation and mitigation at local, regional and even national scales (Lobato-Sánchez, 2016). CONAGUA (2013) identified a long hydrological drought in the Sonora Basin, from 1996 to 2009. Navarro and Moreno (2016) mentioned that the reservoirs "Abelardo Rodriguez" and "El Molinito" have been below the operational level between 1998 and 2014, levels that are not enough to supply water for the City of Hermosillo, Sonora.

Thus, the objective of this study was to analyze meteorological drought temporally and spatially in middle and upper regions of the Sonora River Basin, Mexico, for the period 1974 to 2013 using SPI and SPEI indices at scales of 3, 6, 12 and 24 months. The importance of this study resides in the detailed analysis of the drought described by CONAGUA (2013), highlighting the dramatic situation in northern of Mexico over several years. The study responds to the recommendation of the Drought Monitor with SPI to develop a more detailed study by economic regions. The Sonora basin has experienced an increase in population in recent years and, thus, in water demand by the population and agriculture. 


\section{Materials and methods}

\subsection{Description of the study area}

The Sonora River basin is located in the northeast-central part of the state of Sonora, bounded by the geographic coordinates $28^{\circ} 5^{\prime} 19.23^{\prime \prime}$ and $30^{\circ} 59^{\prime} 18.56^{\prime \prime} \mathrm{N}$ and $109^{\circ} 52^{\prime} 8.92^{\prime \prime}$ and $111^{\circ} 37^{\prime} 52.81^{\prime \prime} \mathrm{W}$, and covering an area of $26,827 \mathrm{~km}^{2}$. The current study includes only middle and upper regions of the basin, $21,220 \mathrm{~km}^{2}$ (Fig. 1).

Mean annual precipitation varies from 300 to $600 \mathrm{~mm}$; the highest values occur toward the northwestern part of the study area and to the south in areas of the Sierra Madre Occidental. Most of the rain falls in summer, associated with the North American Monsoon. However, there are also significant rainfall events in winter, resulting from the impact of extratropical cyclones. Mean annual temperatures range between 12 and $24{ }^{\circ} \mathrm{C}$ (CONABIO, 2020); the lowest values occur in the highest mountainous areas of Cananea, Los Ajos and Aconchi mountain ranges. The municipalities included totally or partially in the study area are Aconchi, Arizpe, Bacoachi, Banámichi, Baviácora, Cananea, Carbó, Cucurpe, Hermosillo, Huépac, Imuris, Opodepe, Rayón, San Felipe de Jesús, San Miguel de Horcasitas and Ures, with a total population estimated at 973,800 by the inter-census survey (INEGI, 2015).

\subsection{Climatic information used}

The series of monthly data on precipitation and maximum and minimum temperatures from a total of 29 stations were obtained from the network of weather stations of the Servicio Meteorológico Nacional (SMN, 2019) for the period 1974 to 2013, that is, 40 years of information. Of these stations, 19 are within the study area and 10 are nearby (Fig. 2).

\subsection{Estimation of missing data}

The series of data with climate information (precipitation and maximum and minimum temperatures) were not complete during the study period, and it was necessary to estimate the missing data. The method of Inverse Distance Weighting (IDW), or the US National Weather Service method, suggested by the World Meteorological Organization (OMM, 2011), was applied. According to Campos-Aranda (1998), the missing data of a station can be estimated based on observed data of the four (preferably), three or two closest stations. Equations 1 and 2 present the formulas that are applicable for this method.

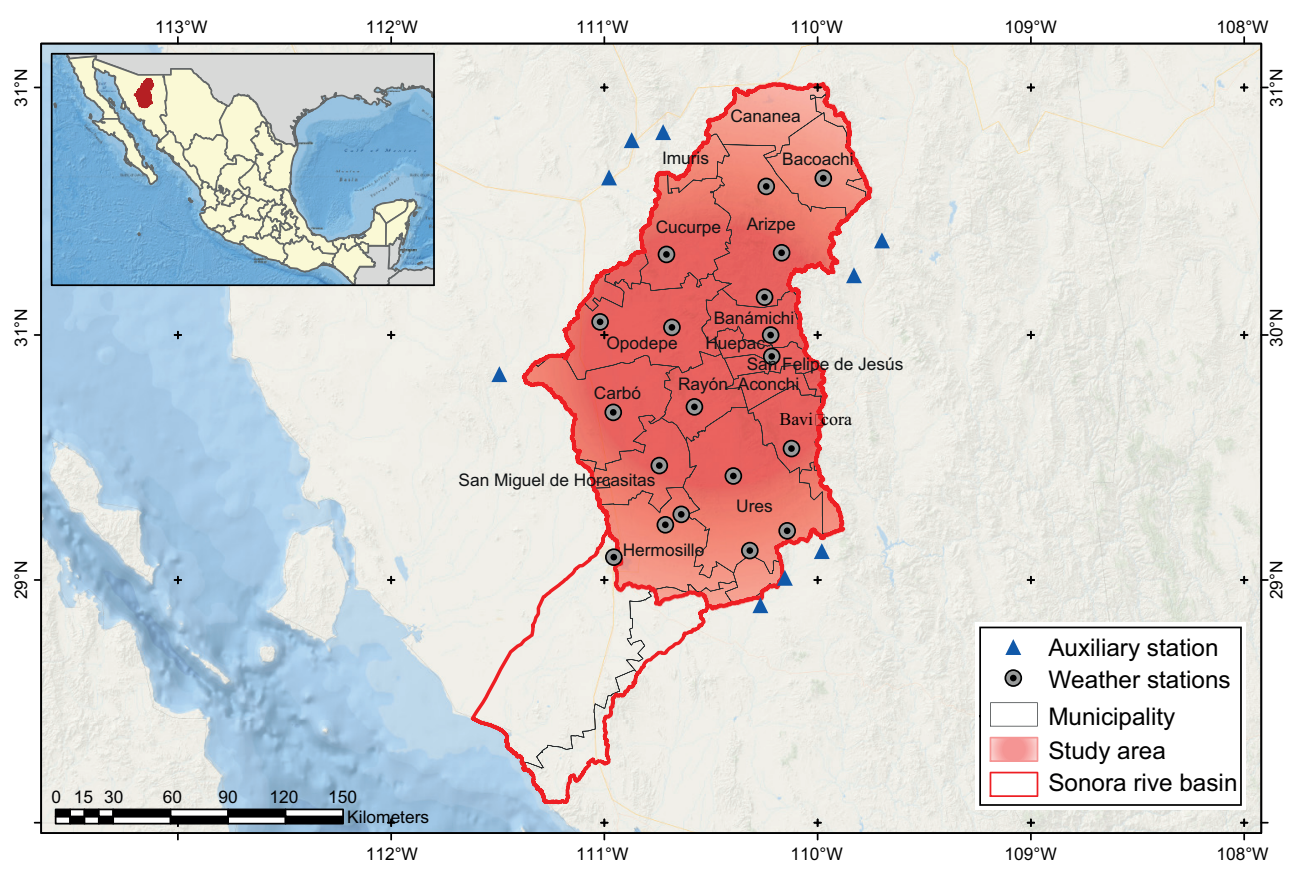

Fig. 1. Location of the study area and of weather stations. 


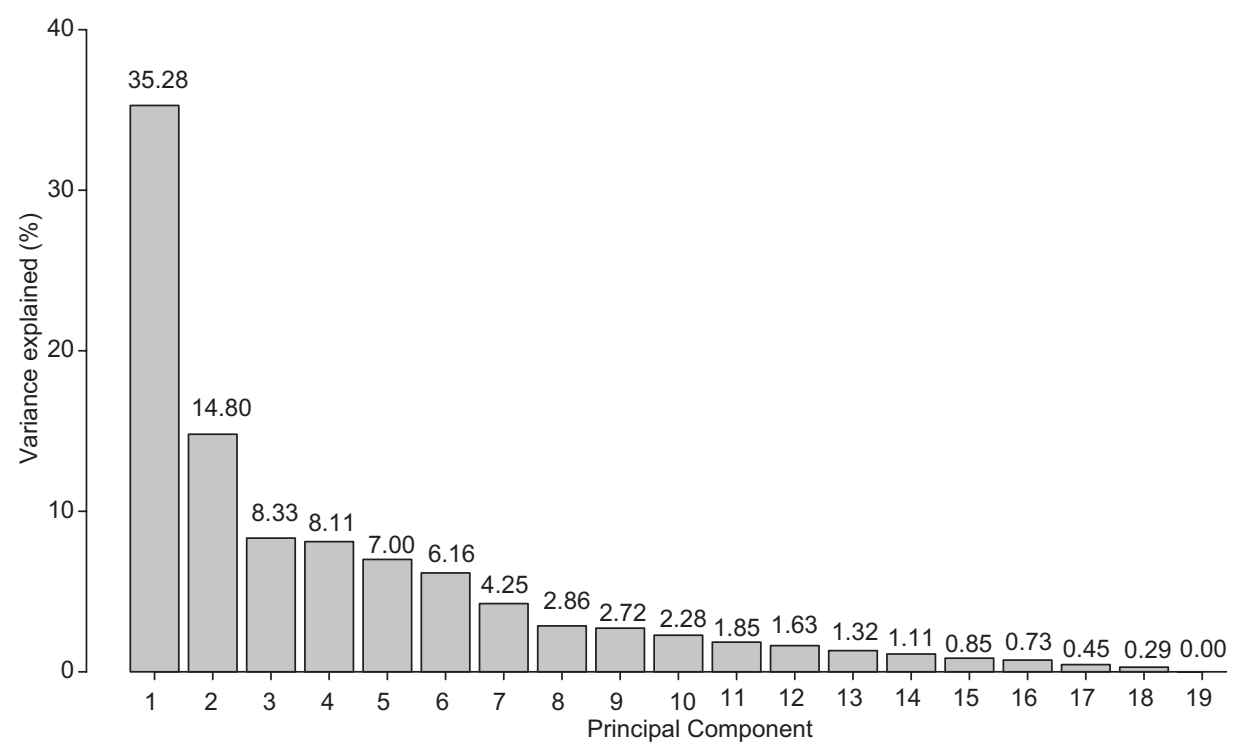

Fig. 2. Total variance explained by each principal component.

$\mathrm{W}_{\mathrm{i}}=\frac{1}{\mathrm{~d}^{2}}$

$\mathrm{D}_{\mathrm{x}}=\frac{\sum_{\mathrm{i}=1}^{\mathrm{N}}\left(\mathrm{D}_{\mathrm{i}} \cdot \mathrm{W}_{\mathrm{i}}\right)}{\sum_{\mathrm{i}=1}^{\mathrm{N}} \mathrm{W}_{\mathrm{i}}}$

where $\mathrm{W}_{\mathrm{i}}$ is equal to the reciprocal of the square of the distance (d) given in $\mathrm{km}$ between each neighboring station with the known data $\left(\mathrm{D}_{\mathrm{i}}\right)$ and the station missing the data $\left(D_{\mathrm{x}}\right)$.

\subsection{Regionalization of the study area}

For the spatial analysis of droughts, first, the climatological data were subjected to meticulous quality control in terms of their continuity, variability and magnitude. When the missing data were estimated with the IDW method to complete the series, the continuity criterion was satisfied. Variability and magnitude of the data were estimated using three standard deviations above or below the mean value of the variable to enable identification of suspicious data, which were analyzed and compared with records of neighboring stations and their validity determined or corrected, as suggested by Cuadrat et al. (2013) and Ravelo et al. (2014).

Homogeneous precipitation regions were determined by grouping meteorological stations so that they would share similar patterns in annual precipitation, using two complementary methodologies. First, mean annual isohyets were plotted manually on the digital elevation model, following the graphic method described by Gómez et al. (2008) where mean annual precipitation, orographic characteristics and wind systems that impact the study area are contemplated. And second, Principal Components Analysis (PCA) was performed using the statistical software RStudio (2018) with the aim of representing the 19 stations by a smaller number (Mallants and Feyen, 1990). Using linear combinations of the original data, the variables, factors, or principal components (PC) that explained successively most of the total variance were calculated (Urrutia and Lemus, 2010). Therefore, a matrix of 19 x 40 was generated, corresponding to the 19 weather stations and the 40 mean annual precipitation records. Finally, with PC1 and PC2, a cluster analysis was performed with Euclidean distance as the method for generating the similarity matrix required for grouping the stations by Partitioning Around Medoids (PAM), also known simply as k-medoids. The advantages of the method are discussed by Estarelles et al. (1992) and Reynolds et al. (2006).

\subsection{Analysis of meteorological droughts}

There is a wide variety of indices and equations to quantify a drought and characterize it by intensity, 
duration and frequency. In our study, SPI (Standardized Precipitation Index) and SPEI (Standardized Precipitation Evapotranspiration Index) were calculated at temporal scales of 3, 6, 12 and 24 months for the time series spanning from January 1974 to December 2013.

SPI was calculated following the methodology developed by McKee et al. (1993), using monthly historical records of precipitation $(\mathrm{P})$ to establish a probability of occurrence by fitting them to a gamma distribution. The fitted values are transformed to a normal distribution.

Calculation of SPEI followed the methodology of Vicente-Serrano et al. (2010) where the temperature component is included to enable estimation of evapotranspiration (ETP). ETP is subtracted from precipitation, generating a climatic water balance (P-ETP); this water balance is fit to a log logistic distribution, to later transform it to a normal standard distribution.

Evapotranspiration was calculated by the Hargreaves method modified by Droogers and Allen (2002), which contemplates average monthly temperature $\left(T_{\text {avg }}\right)$, computed as the difference between maximum and minimum temperatures, both in degrees Celsius, precipitation in $\mathrm{mm}(P)$, difference between maximum and minimum temperature $(T D)$, and radiation in $M J m^{-2} d^{-1}(R A)$. Expression (3) represents this reference evapotranspiration $\left(E T_{\mathrm{o}}\right)$.

$\mathrm{ET}_{0}=0.0013 \cdot 0.408 \cdot \mathrm{RA}$.

$\left(\mathrm{T}_{\mathrm{avg}}+17.0\right) \cdot(\mathrm{TD}-0.0123 \cdot \mathrm{P})^{0.76}$

Radiation, $R A$, resulted from the equation proposed by the United Nations Food and Agriculture Organization (Allen et al., 2006).

The temporal scale used indicated the accumulated period of the input variable (P for SPI and P-ETP for SPEI) to calculate each index. Thus, for the scale of three months, the cumulative input variable of the month of interest and the two previous months is considered. For the scale of six months, the cumulative would be the month of interest plus the five previous months, and so forth.

The SPI and SPEI values, being standardized, can correlate with episodes of humidity and drought. The results are interpreted based on the categories used by the Drought Monitor of Mexico (DMM), whose principal objective is to describe drought evolution in terms of magnitude and spatial extension (Lobato-Sánchez, 2016) and is part of the North American Drought Monitor (NADM) (Table I).

Table I. Categories of drought intensity of the North American Drought Monitor.

\begin{tabular}{lcl}
\hline Range & Code & Category \\
\hline SI $\geq 2.0$ & W4 & Exceptionally humid \\
$1.6 \leq$ SI $<2.0$ & W3 & Extremely humid \\
$1.3 \leq$ SI $<1.6$ & W2 & Severely humid \\
$0.8 \leq$ SI $<1.3$ & W1 & Moderately humid \\
$0.5 \leq$ SI $<0.8$ & W0 & Abnormally humid \\
$-0.5<$ SI $<0.5$ & N & Normal conditions \\
$-0.8<$ SI $\leq-0.5$ & D0 & Abnormally dry \\
$-1.3<$ SI $\leq-0.8$ & D1 & Moderately dry \\
$-1.6<$ SI $\leq-1.3$ & D2 & Severely dry \\
$-2.0<$ SI $\leq-1.6$ & D3 & Extremely dry \\
SI $\leq-2.0$ & D4 & Exceptionally dry \\
\hline
\end{tabular}

$\mathrm{SI}=$ Standardized index of drought (SPI, SPEI)

SPI and SPEI were calculated with the software SPEI.R for the RStudio program (2018) developed by Begueria and Vicente-Serrano (2017).

Once time series of SPI and SPEI for each of the 19 weather stations were calculated and categorized, the results were aggregated by homogeneous precipitation regions (isohyets). Droughts were identified from the series of aggregated values at different temporal scales, as well as their intensity, duration, frequency, and trend. Intensity was determined based on the categories in Table I. Duration was estimated based on initial and final dates of those indices. Frequency was determined with the number of times that category occurred (Fig. 9). Trend was estimated by linear regression of SPI and SPEI and was plotted as the average slope of both tendencies (Fig. 5, 6, 7 and, 8).

\section{Results and discussion}

\subsection{Regionalization of the study area}

Weather stations were grouped according to mean annual precipitation into: group 1 (300 to $400 \mathrm{~mm}$ ), group 2 (400 to $500 \mathrm{~mm}$ ) and group 3 (500 to $600 \mathrm{~mm}$ ). A correlation matrix between stations was constructed, with values ranging between 0.30 and 0.84 , with 
a mean of 0.62 , and a determinant of $2.2210^{-11}$. According to Urrutia and Lemus (2010), if a low determinant value different from zero is obtained, it indicates high intercorrelations between variables (stations), which is our case, and gives rise to factorial analysis of the principal components (PC). Figure 2 shows that the first two PC are the most important, explaining $35.28 \%$ and $14.80 \%$ of the total variability between stations, with respect to mean annual precipitation. This previous conclusion is based on Vicario et al. (2015), who conducted a study with series of monthly precipitation data from 15 stations in the provinces of Córdoba, Santa Fe and Entre Ríos, Argentina for a period of 30 years. Their results revealed that $\mathrm{PC} 1$ and $\mathrm{PC} 2$ explained $75.1 \%$ of the observed variability between the stations and annual mean precipitation. Urrutia and Lemus (2010) found that the first two components explained $74 \%$ of the variance when they determined homogeneous patterns of temperature in six stations of the Department of Chocó, Colombia.

Figure 3 shows the dispersion diagram from the cluster analysis of the stations obtained from PC1 and $\mathrm{PC} 2$ grouped according to the behavior patterns of average annual precipitation. The isohyets generated ahead of grouping the 19 stations into $\mathrm{k}=3$ groups were taken as reference. Vicario et al. (2015) analyzed physical and pluviometric characteristics of 15 weather stations and also generated three groups with similar behavior; their study differed in that they used the average chain-linking method.
Contrasting results of the methodologies used for regionalization revealed a discrepancy in station 26271-Sinoquipe. With a record of average annual precipitation of $504.5 \mathrm{~mm}$, it was placed in the polygon of isohyets of 500-600 mm (group 3). However, the PCA placed it in group 2, where we finally left it after analyzing its geographic location and the pluviometric characteristic of the series, redefining the corresponding isohyet.

Groups 1 and 3 consist of four stations each, and group 2 contained eleven. This last group was divided into two subgroups ( $2 \mathrm{a}$ and $2 \mathrm{~b}$ ), according to the physiography of the site. Stations in groups 1 and $2 \mathrm{a}$ are found within the physiographic province of the Sonora plains, while group $2 b$ and 3 are in the physiographic region of the Sierra Madre Occidental, with the particularity that group $2 b$ is in the intermountain valleys that form the Aconchi, Cananea and Los Ajos mountain ranges. The list of weather stations analyzed and the groups to which they belong are presented in Table II and Figure 4 locates them spatially within the generated isohyets.

\subsection{Analysis of meteorological droughts}

The results of the analysis of meteorological droughts are presented by groups of stations (homogeneous precipitation regions) for which the SPI and SPEI historical series of the weather stations were averaged, and series of mean values for the different temporal scales used were obtained.

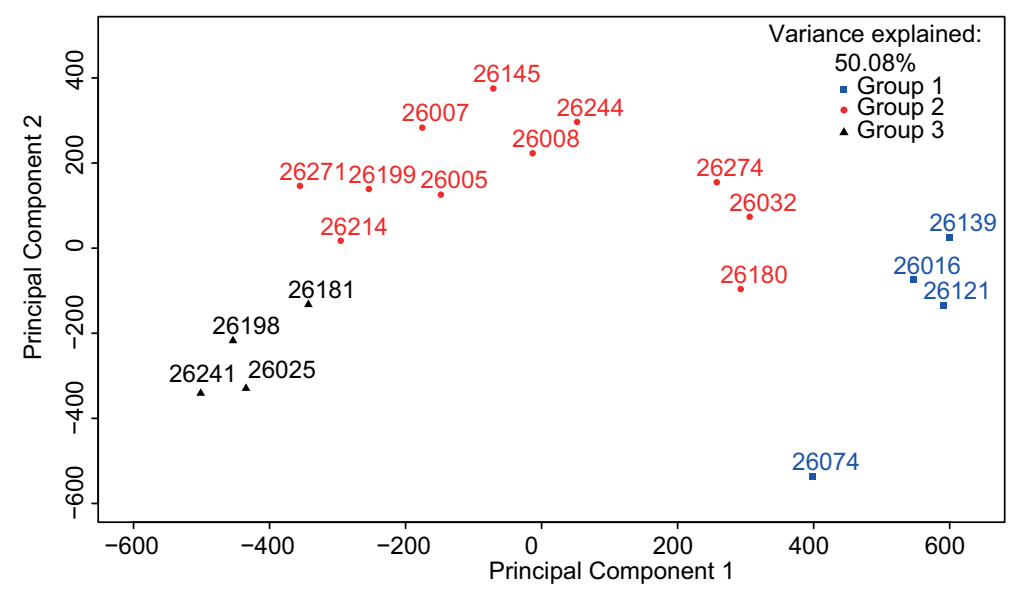

Fig. 3. Groups of weather stations defined by PCA. 


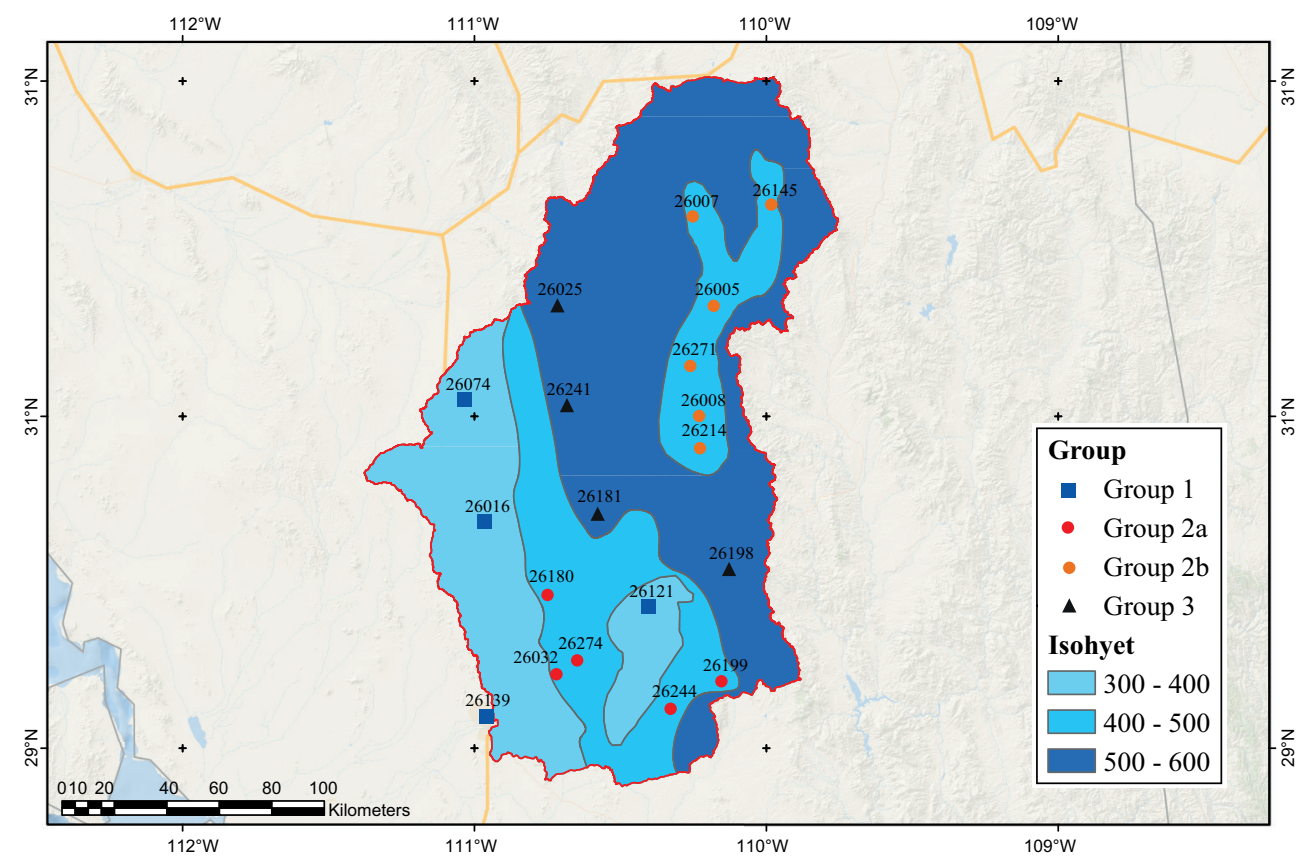

Fig. 4. Mean annual isohyets and grouped weather stations.

Table II. Selected weather stations in the study area.

\begin{tabular}{|c|c|c|c|c|c|c|c|c|c|c|}
\hline Station & & Altitude & $\begin{array}{l}\text { Latitude } \\
(\mathrm{N})\end{array}$ & $\begin{array}{l}\text { Longitude } \\
\text { (W) }\end{array}$ & $\begin{array}{c}\mathrm{P} \\
(\mathrm{mm})\end{array}$ & $\begin{array}{c}\text { Tmax } \\
\left({ }^{\circ} \mathrm{C}\right)\end{array}$ & $\begin{array}{l}\text { Tmin } \\
\left({ }^{\circ} \mathrm{C}\right)\end{array}$ & $\begin{array}{l}\text { Est. } \\
\text { Dat. } \\
(\%)\end{array}$ & Group & $\begin{array}{l}\text { Isohyet } \\
(\mathrm{mm})\end{array}$ \\
\hline 26139 & Hermosillo II & 221 & $29^{\circ} 05^{\prime} 56^{\prime \prime}$ & $110^{\circ} 57^{\prime} 14^{\prime \prime}$ & 363.5 & 32.2 & 17.7 & 0.3 & \multirow{4}{*}{1} & \multirow{4}{*}{$300-400$} \\
\hline 26121 & Ures & 385 & $29^{\circ} 25^{\prime} 37^{\prime \prime}$ & $110^{\circ} 23^{\prime} 31^{\prime \prime}$ & 375.6 & 31.8 & 9.1 & 12.1 & & \\
\hline 26016 & Carbo & 464 & $29^{\circ} 41^{\prime} 03^{\prime \prime}$ & $110^{\circ} 57^{\prime} 18^{\prime \prime}$ & 374.6 & 31.2 & 13.0 & 4.9 & & \\
\hline 26074 & Querobabi & 661 & $30^{\circ} 03^{\prime} 02^{\prime \prime}$ & $111^{\circ} 01^{\prime} 17^{\prime \prime}$ & 394.0 & 31.2 & 11.3 & 12.1 & & \\
\hline 26032 & El Orégano & 279 & $29^{\circ} 13^{\prime} 48^{\prime \prime}$ & $110^{\circ} 42^{\prime} 21^{\prime \prime}$ & 410.6 & 33.8 & 14.1 & 6.9 & \multirow{5}{*}{$2 \mathrm{a}$} & \multirow{11}{*}{$400-500$} \\
\hline 26274 & Topahue & 300 & $29^{\circ} 16^{\prime} 15^{\prime \prime}$ & $110^{\circ} 38^{\prime} 09^{\prime \prime}$ & 418.6 & 33.1 & 12.9 & 22.4 & & \\
\hline 26180 & El Cajón & 390 & $29^{\circ} 28^{\prime} 19^{\prime \prime}$ & $110^{\circ} 44^{\prime} 09^{\prime \prime}$ & 414.2 & 32.1 & 11.7 & 2.3 & & \\
\hline 26244 & Rancho Viejo & 450 & $29^{\circ} 07^{\prime} 37^{\prime \prime}$ & $110^{\circ} 18^{\prime} 54^{\prime \prime}$ & 458.6 & 31.1 & 12.4 & 28.1 & & \\
\hline 26199 & Pueblo de Álamos & 589 & $29^{\circ} 12^{\prime} 15^{\prime \prime}$ & $110^{\circ} 08^{\prime} 25^{\prime \prime}$ & 498.8 & 30.8 & 11.7 & 15.8 & & \\
\hline 26214 & Huepac & 644 & $29^{\circ} 54^{\prime} 46^{\prime \prime}$ & $110^{\circ} 12^{\prime} 47^{\prime \prime}$ & 496.5 & 30.1 & 9.7 & 19.7 & \multirow{6}{*}{$2 b$} & \\
\hline 26008 & Banamichi & 675 & $30^{\circ} 00^{\prime} 12^{\prime \prime}$ & $110^{\circ} 12^{\prime} 54^{\prime \prime}$ & 459.7 & 30.7 & 13.3 & 1.7 & & \\
\hline 26271 & Sinoquipe & 740 & $30^{\circ} 09^{\prime} 20^{\prime \prime}$ & $110^{\circ} 14^{\prime} 42^{\prime \prime}$ & 504.5 & 30.5 & 11.6 & 39.8 & & \\
\hline 26005 & Arizpe & 836 & $30^{\circ} 20^{\prime} 08^{\prime \prime}$ & $110^{\circ} 10^{\prime} 03^{\prime \prime}$ & 474.5 & 29.4 & 10.0 & 31.9 & & \\
\hline 26007 & Bacanuchi & 1049 & $30^{\circ} 35^{\prime} 56^{\prime \prime}$ & $110^{\circ} 14^{\prime} 18^{\prime \prime}$ & 489.1 & 28.0 & 7.4 & 6.2 & & \\
\hline 26145 & Bacoachi & 1049 & $30^{\circ} 37^{\prime} 54^{\prime \prime}$ & $109^{\circ} 58^{\prime} 12^{\prime \prime}$ & 465.5 & 28.0 & 8.2 & 35.3 & & \\
\hline 26198 & Mazocahui & 449 & $29^{\circ} 32^{\prime} 26^{\prime \prime}$ & $110^{\circ} 07^{\prime} 09^{\prime \prime}$ & 517.6 & 31.4 & 11.2 & 22.1 & \multirow{4}{*}{. } & \multirow{4}{*}{$500-600$} \\
\hline 26181 & Rayón & 560 & $29^{\circ} 42^{\prime} 38^{\prime \prime}$ & $110^{\circ} 34^{\prime} 14^{\prime \prime}$ & 500.5 & 30.6 & 11.8 & 7.7 & & \\
\hline 26241 & Meresichic & 712 & $30^{\circ} 01^{\prime} 50^{\prime \prime}$ & $110^{\circ} 40^{\prime} 30^{\prime \prime}$ & 521.8 & 28.5 & 11.0 & 38.9 & & \\
\hline 26025 & Cucurpe & 853 & $30^{\circ} 19^{\prime} 50^{\prime \prime}$ & $110^{\circ} 42^{\prime} 21^{\prime \prime}$ & 524.7 & 29.6 & 10.3 & 10.4 & & \\
\hline
\end{tabular}

$\mathrm{P}=$ Average annual precipitation, $\mathrm{Tmax}=$ Average maximum temperature, Tmin $=$ Average minimum temperature, Est. Dat. $=$ Estimated data. 
Figure 5 shows the series of average SPI and SPEI values for the stations of group 1 (Hermosillo, Ures, Carbo and Querobabi) where in 1982, 1997, 1999, 2010, 2011 and 2013 at all temporal scales reported droughts of some degree of intensity. Extreme events occurred from August to December 1982 and January 2011 to July 2012, with intervals of exceptional drought in July 1982, March to May and September to October 2011, and in January to June 2012. CONAGUA (2013) reported periods of exceptional drought from 1999 to 2001 and severe drought events in 2004 to 2006 for the Carbo station.

In general, there are great similarities among the behavior of time series of drought indices; that is, drought occurrence is similar when they belong to the same group of weather stations. However, with SPI, on average, $28 \%$ of all the registers were identified with some degree of drought, while with SPEI, it was $30 \%$. The slope obtained from the time series fit to a linear regression model provided an estimate of the trend; in general, the trend is negative for all temporal scales.

The series of average SPI and SPEI values for group 2a, comprising El Orégano, Topahue, El Cajón, Rancho Viejo and Pueblo de Álamos, are presented in Figure 6. Exceptional drought events were identified in May 1999, March 2006 and June 2011, and droughts of less intensity in 1980, 1987, 1997-2000, 2006, and 2011 at all temporal scales. The longest drought, according to SPI and SPEI at the temporal scale of 24 months, occurred from September 1987 to June 1989 with moderate intensity. CONAGUA (2013) reported that, as of 1996, the hydrometric stations El Cajón and El Orégano registered a decrease in runoff, and the negative trend has continued in recent years.

The time behavior is similar for both indices; on average, $30 \%$ and $32 \%$ of all records indicate some degree of drought for SPI and SPEI, respectively. The latter index evaluates drought periods more rigorous-

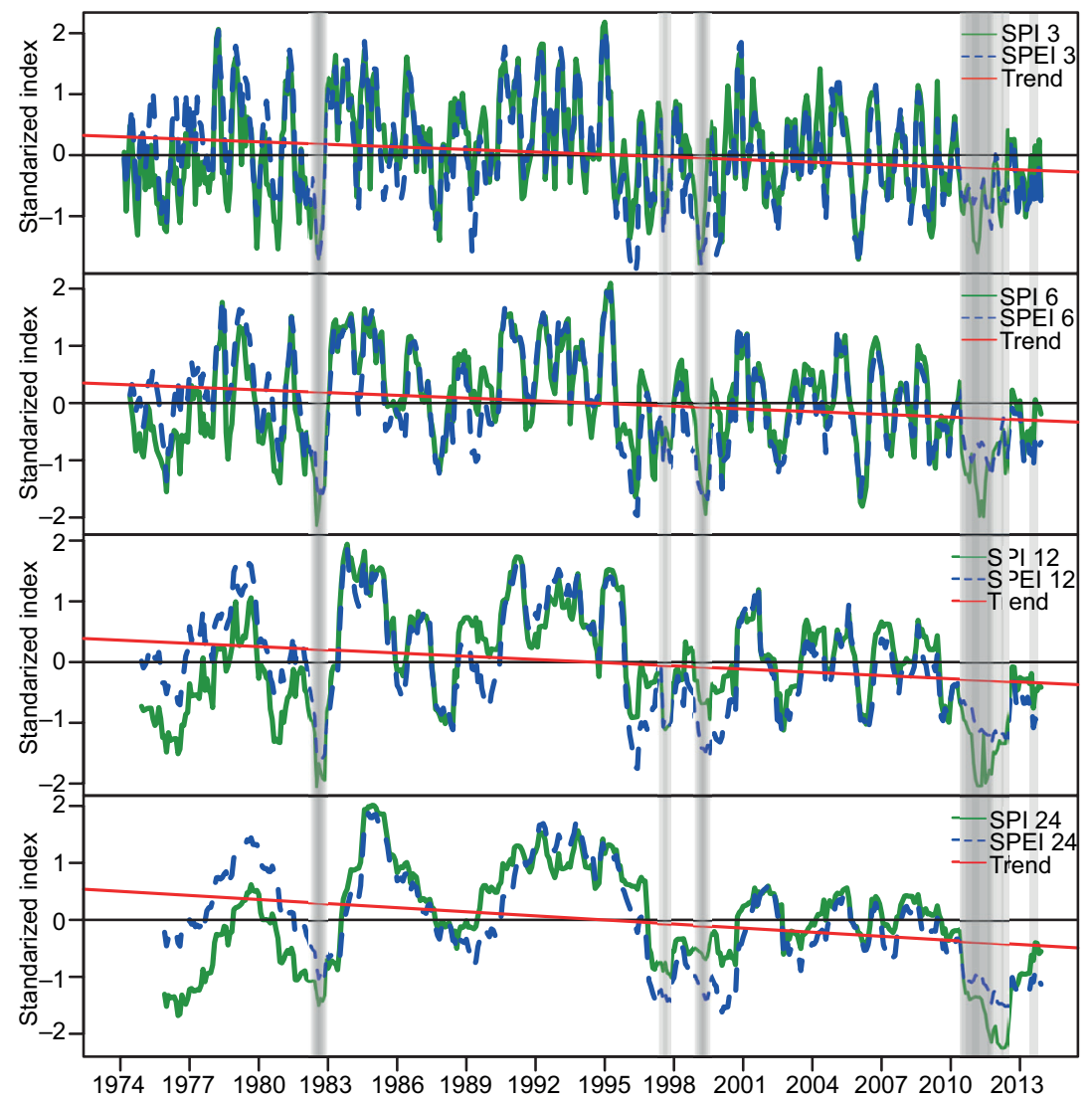

Fig. 5. Time series of mean SPI and SPEI for group 1. 


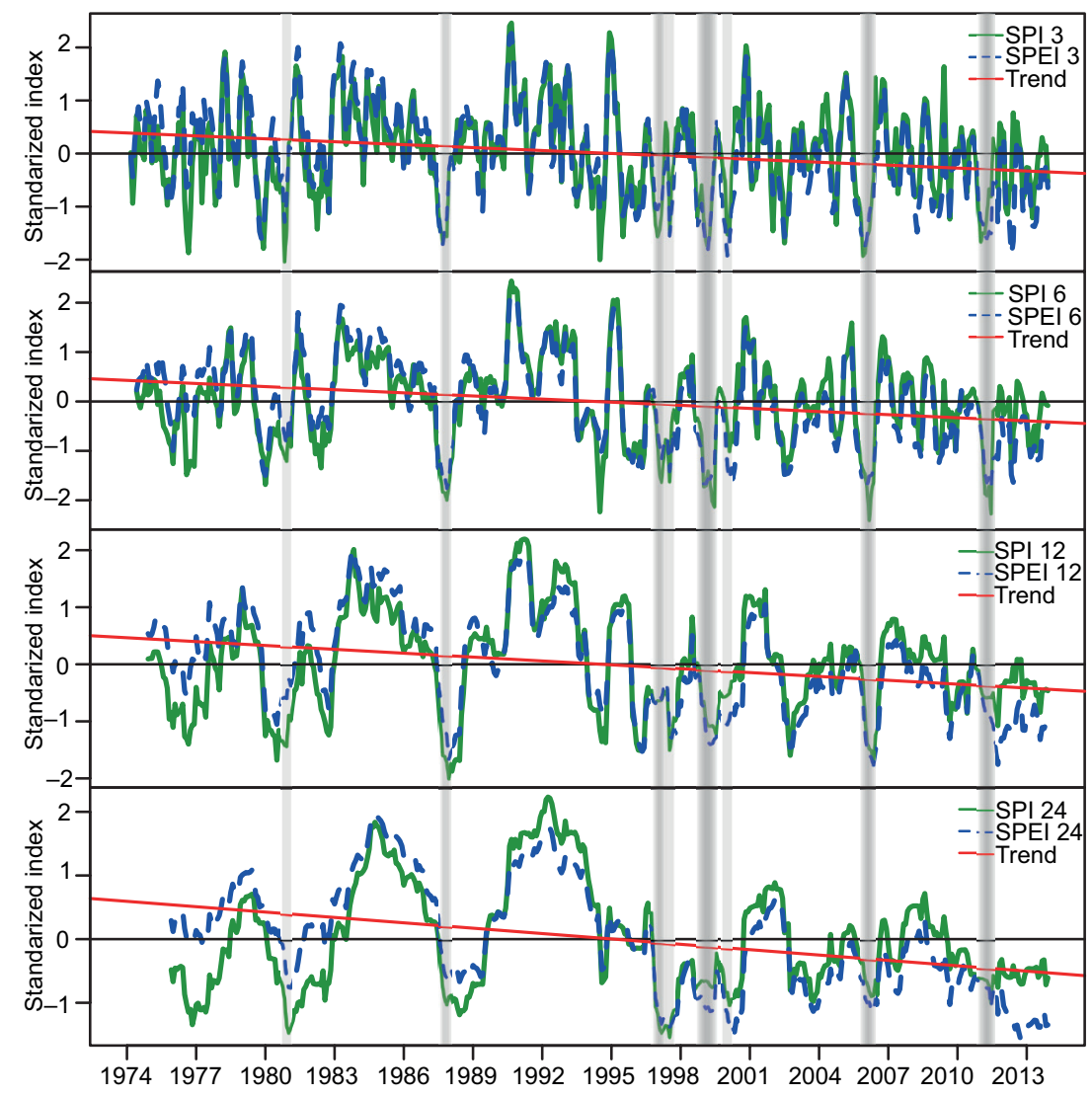

Fig. 6. Time series of mean SPI and SPEI for group 2a.

ly at the end of the series, and the trend estimated by linear regressions was negative for all time series.

Figure 7 presents the temporal series of mean values for the SPI and SPEI indices obtained from averaging values at stations in group $2 b$ (Huepac, Banamichi, Sinoquipe, Arizpe, Bacanuchi and Bacoachi). All time scales indicate simultaneous drought events in 1980, 1997, 1999-2003 and 20112013, although of shorter duration than for groups 1 and $2 \mathrm{a}$. In contrast, the longest events detected by both indices at a scale of 24 months occurred from July 1998 to October 2000 and from August 2010 to December 2013, with abnormal to severe intensities in both cases. Within the drought period October 2002 to January 2005, there was an extreme event from July 2003 to February 2004. However, CONAGUA (2013) in reports of the Alto Noroeste Basin Council, indicates that the northwestern part presents extreme drought from March to November 2011, affecting the municipalities of Naco, Santa Cruz, Cananea,
Bacoachi, Arizpe, Banámichi, Huépac, Aconchi, Baviacora, Ures, west Altar, Trincheras, Carbó and east Hermosillo. For this group, on average, a moisture deficit of $29 \%$ was registered by SPI and $32 \%$ by SPEI. The trend represented by the slope of the linear regression fit of the data is negative for all cases.

For group 3 (Mazocahui, Rayón, Meresichic and Cucurpe), Figure 8 shows the average SPI and SPEI time series. Note that in 1975, 1976, 1997, 2000 and 2011-2013 there are drought events that synchronize in all time scales. Of the longest events in this group, those that occurred from December 1974 to February 1978 detected in the SPI 12-month series is outstanding. Another outstanding event detected in the SPI 24-month series lasted from August 2010 to December 2013. Both cases had moderate intensity and the 24-month SPEI categorized the event that occurred from July 1976 to June 1977 as extreme. Likewise, in December 2012, CONAGUA (2013) declared 11 municipalities of Sonora a disaster zone 


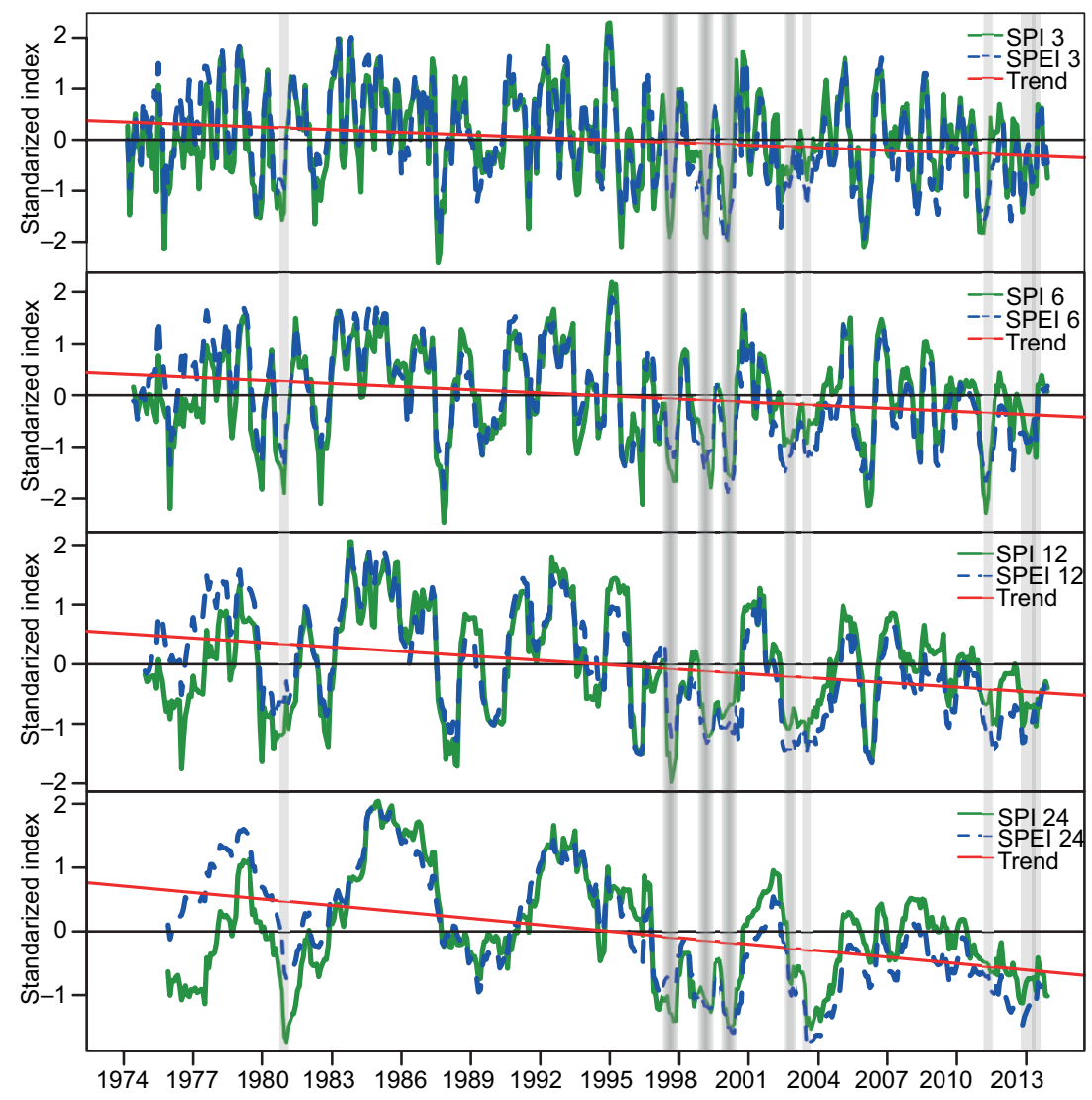

Fig. 7. Time series of mean SPI and SPEI for group $2 b$.

because of severe drought, among which was $\mathrm{Cu}-$ curpe. On average, of the different scales used, SPI detected 142 cases of drought, while SPEI found 138. The trend of the time series is negative, with a less steep slope as compared with the group of stations analyzed previously.

Figure 10 shows how precipitation and evapotranspiration behave in a wet year and in a dry year. Notice how in all months of the dry year (2011) there is a negative water balance (P-ETP). But also notice that even in a wet year (1994), a negative balance is observed. For this reason, we strongly recommend the use of the SPEI index to characterize drought in the Sonora basin.

Table III presents the descriptive statistics by groups of stations of the series of mean SPI and SPEI values at the different scales. The mean is near zero and the standard deviation near one (parameters of a normal standard distribution).
Table IV lists drought events according to the intensity detected by SPI and SPEI for each group of stations at 3, 6, 12 or 24 months, while in Figure 9 they are expressed in percentage in a frequency graph. In general, moderate droughts dominate in groups 1 , $2 \mathrm{a}$ and $2 \mathrm{~b}$, while group 3 mostly presents abnormally dry conditions.

It should be mentioned that, on average, SPEI detected a higher number of drought events at the different scales, as well as a trend with a pronounced negative slope, which means an increase in intensity and demonstrates the relevance of including variables such as evapotranspiration to study droughts. However, SPI more often characterized exceptional droughts. This behavior was also reported by Serrano-Barrios et al. (2016) when they analyzed droughts in the north Pacific basin between 1961 and 2010. In a similar way, Campos-Aranda (2018), Castillo-Castillo et al. (2017) and Vicente-Serrano et al. (2012) 


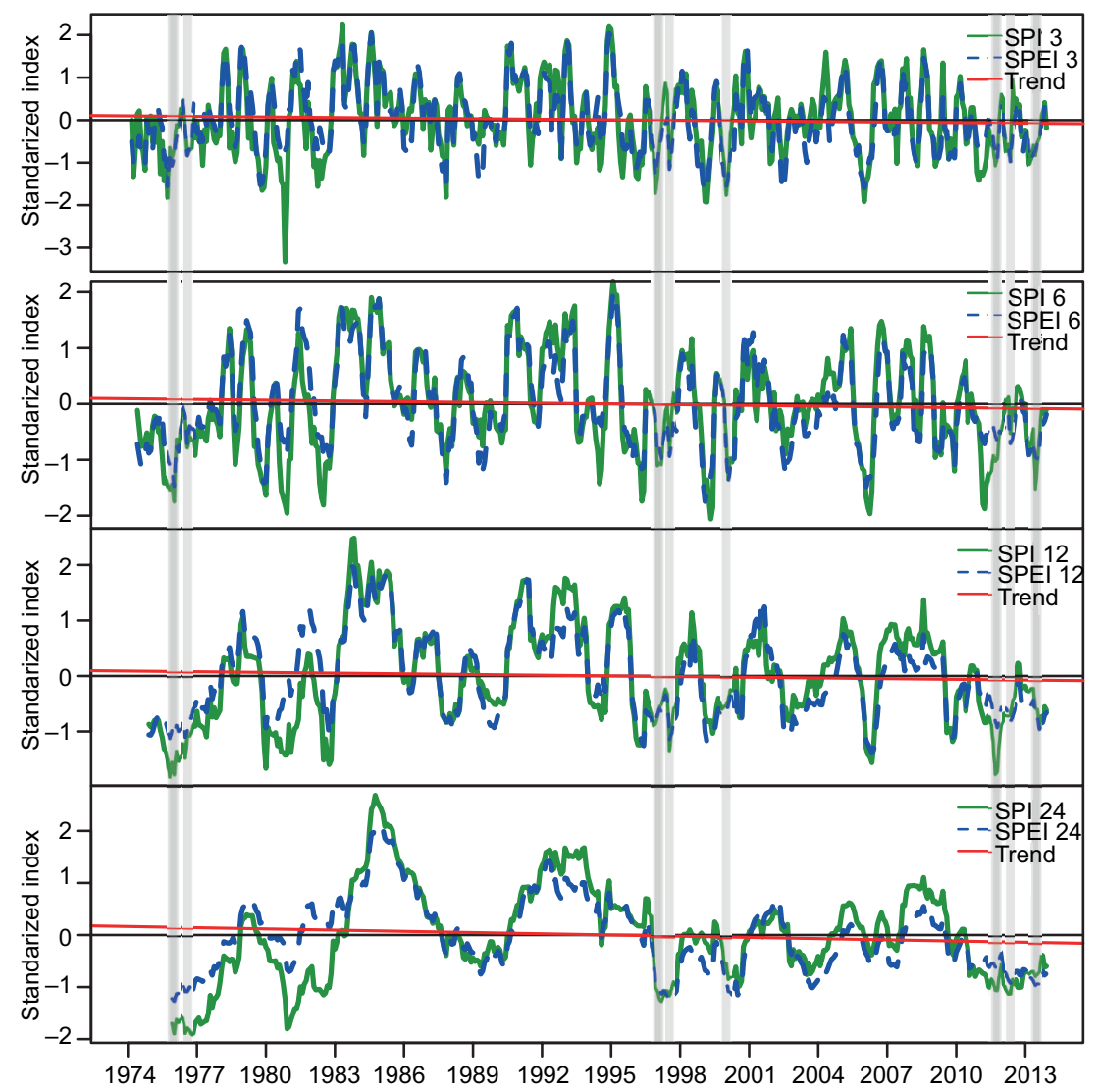

Fig. 8. Time series of mean SPI and SPEI for group 3.

concluded that temperature should be included when studying droughts.

In general, droughts were detected in 1997 and 2011. In 1999 and 2000 important events occurred in most of the study area, with the exception of groups 3 and 1 in the respective years. These results agree with those reported by Sthale et al. (2009), who stated that from 1994 to the early $21^{\text {st }}$ century droughts have been more severe and sustained throughout Mexico. Similarly, Castillo-Castillo et al. (2017) found two periods of extreme drought from 1999 to 2004 and from 2011 to 2012 in the Fuerte River basin located in northwestern Mexico. CONAGUA (2013) reported droughts from 1999 to 2007, analyzing SPI, SPEI and the Palmer index. CONAGUA analyses detected the May-November 2011 droughts, occurring with some degree of intensity in practically $50 \%$ of the country's territory, affecting agriculture and livestock in the north of Mexico. It is worth mentioning that Eakin et al.(2007) described serious problems of lack of available water in the state of Sonora in the 1990s caused by a decrease in precipitation, and a severe drought was declared. Also, the reports of CONAGUA (2010) and Navarro and Moreno (2016) agree with results presented here.

Finally, it is important to mention that the official Mexican agency responsible for following up the evolution of this phenomenon is the Servicio Meteorológico Nacional (SMN) supported by the Drought Monitor of Mexico (DMM), which is part of the North American Drought Monitor (NADM). DMM methodology is based on estimating and interpreting several indices, including SPI, one of the most frequently used in North America (Velasco et al., 2004). However, our study showed that SPEI was useful and has potential for detection of droughts. While the SMN drought monitor gives a general view of the country, it is better to monitor drought specifically and in detail at basin level to enable better planning when dealing with droughts. 


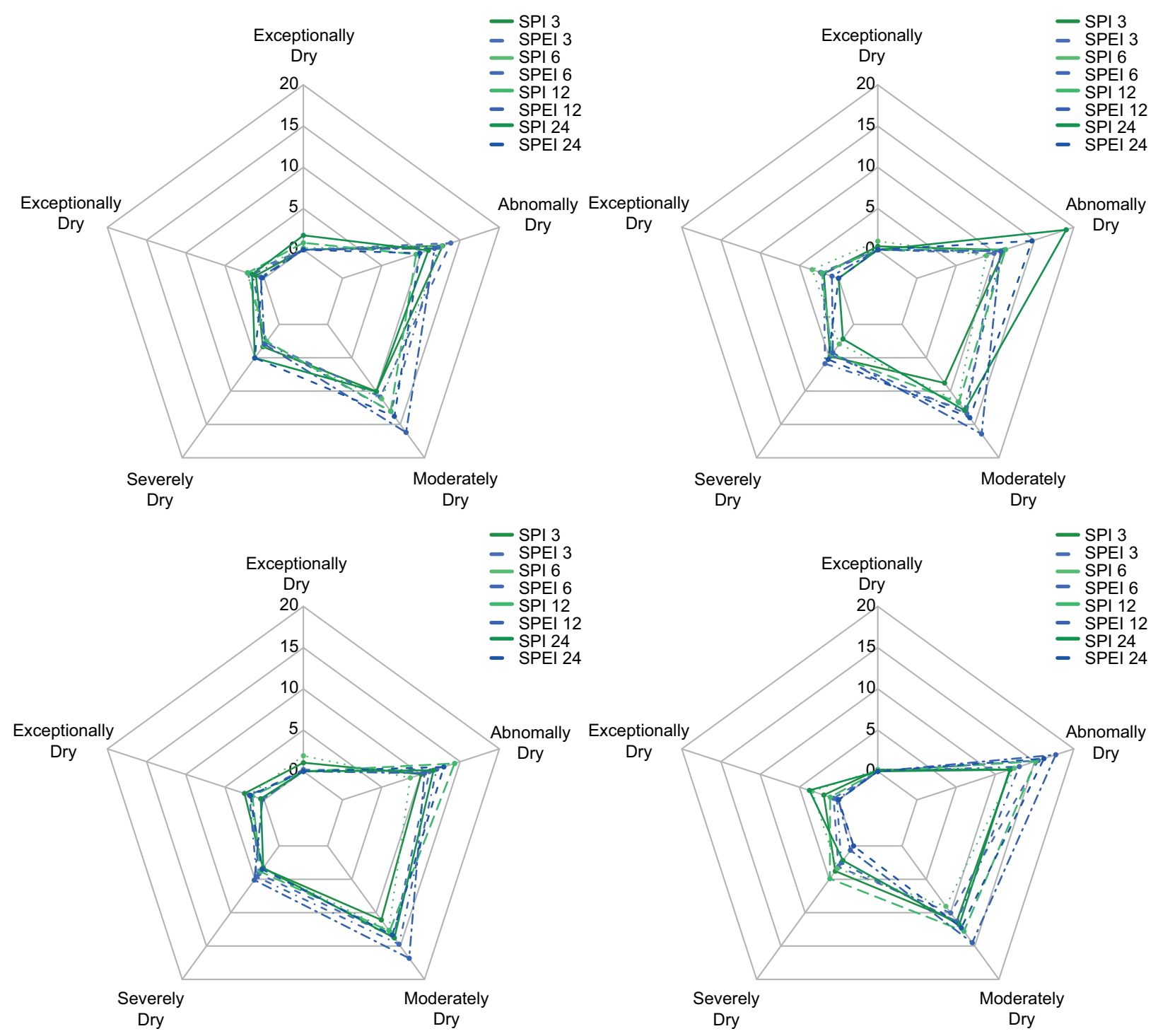

Fig. 9. Frequency of occurrence of drought events by group of stations.
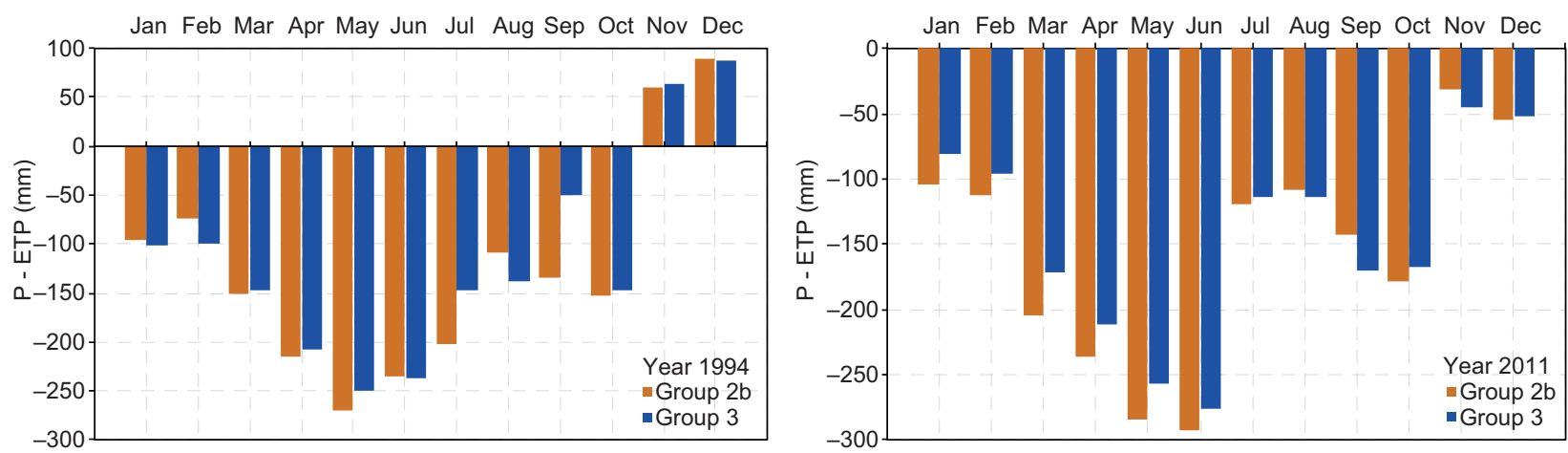

Fig. 10. Hydrological balance (P-ETP), for a wet year (left) and a dry year (right). 
Table III. Descriptive statistics of the average time series of SPI and SPEI at different temporal scales by group of stations.

\begin{tabular}{|c|c|c|c|c|c|c|c|c|c|c|c|}
\hline & \multirow{2}{*}{ SPI } & \multicolumn{4}{|c|}{ Group } & & \multirow{2}{*}{ SPEI } & \multicolumn{4}{|c|}{ Group } \\
\hline & & 1 & $2 a$ & $2 b$ & 3 & & & 1 & $2 a$ & $2 b$ & 3 \\
\hline \multirow{4}{*}{3} & Drought ( \%) & 27.20 & 26.99 & 28.03 & 29.08 & \multirow{4}{*}{3} & Drough ( \%) & 29.50 & 30.13 & 30.75 & 29.29 \\
\hline & Min. & -1.78 & -2.04 & -2.41 & -3.34 & & Min. & -1.96 & -1.93 & -2.01 & -1.68 \\
\hline & Mean & 0.04 & 0.03 & 0.02 & 0.02 & & Mean & 0.01 & 0.01 & 0.01 & 0.01 \\
\hline & S.D. & 0.80 & 0.84 & 0.88 & 0.85 & & S.D. & 0.82 & 0.88 & 0.88 & 0.79 \\
\hline \multirow{4}{*}{6} & Drought ( \%) & 29.26 & 27.79 & 28.42 & 28.42 & \multirow{4}{*}{6} & Drought ( $\%)$ & 29.47 & 31.37 & 33.26 & 27.16 \\
\hline & Min. & -2.13 & -2.40 & -2.46 & -2.06 & & Min. & -1.97 & -1.75 & -1.89 & -1.75 \\
\hline & Mean. & 0.01 & 0.00 & 0.00 & 0.00 & & Mean & 0.01 & 0.00 & 0.00 & 0.01 \\
\hline & S.D. & 0.83 & 0.88 & 0.88 & 0.87 & & S.d. & 0.82 & 0.88 & 0.88 & 0.79 \\
\hline \multirow{4}{*}{12} & Drought ( \%) & 27.93 & 29.64 & 32.41 & 33.90 & \multirow{4}{*}{12} & Drought ( $\%)$ & 31.34 & 32.20 & 32.62 & 32.84 \\
\hline & Min. & -2.04 & -1.99 & -1.97 & -1.81 & & Min. & -1.75 & -1.76 & -1.66 & -1.39 \\
\hline & Mean. & 0.00 & 0.00 & 0.00 & 0.01 & & Mean. & 0.00 & 0.00 & 0.00 & 0.00 \\
\hline & S.D & 0.84 & 0.85 & 0.84 & 0.87 & & S.D. & 0.83 & 0.87 & 0.87 & 0.76 \\
\hline \multirow{4}{*}{24} & Drought ( $\%)$ & 29.32 & 34.14 & 29.10 & 29.54 & \multirow{4}{*}{24} & Drought ( $\%)$ & 28.88 & 33.92 & 31.51 & 28.45 \\
\hline & Min. & -2.23 & -1.52 & -1.72 & -1.89 & & Min. & -1.62 & -1.60 & -1.78 & -1.25 \\
\hline & Mean. & 0.00 & 0.00 & 0.00 & 0.00 & & Mean. & 0.00 & 0.01 & 0.00 & 0.00 \\
\hline & S.D. & 0.87 & 0.85 & 0.83 & 0.90 & & S.D. & 0.85 & 0.86 & 0.87 & 0.71 \\
\hline
\end{tabular}

Drought $(\%)=$ Drought in \%, Min.= Minimum, S.D. = Standard deviation.

Table IV. Frequency of occurrence of drought events.

\begin{tabular}{lccccccccc}
\hline Drought & Group & SPI 3 & SPEI 3 & SPI 6 & SPEI 6 & SPI 12 & SPEI 12 & SPI 24 & SPEI 24 \\
\hline \multirow{5}{*}{ Exceptional } & 1 & 0 & 0 & 1 & 0 & 4 & 0 & 8 & 0 \\
& $2 \mathrm{a}$ & 2 & 0 & 5 & 0 & 0 & 0 & 0 & 0 \\
& $2 \mathrm{~b}$ & 5 & 1 & 9 & 0 & 0 & 0 & 0 & 0 \\
Extreme & 3 & 1 & 0 & 1 & 0 & 0 & 0 & 0 & 0 \\
\hline \multirow{5}{*}{ Severe } & 1 & 5 & 10 & 10 & 7 & 10 & 2 & 7 & 1 \\
& $2 \mathrm{a}$ & 9 & 11 & 16 & 9 & 10 & 4 & 0 & 0 \\
& $2 \mathrm{~b}$ & 12 & 8 & 9 & 9 & 7 & 1 & 2 & 8 \\
& 3 & 9 & 3 & 16 & 1 & 5 & 0 & 17 & 0 \\
\hline \multirow{5}{*}{ Moderate } & 1 & 16 & 13 & 15 & 13 & 12 & 14 & 23 & 23 \\
& $2 \mathrm{a}$ & 23 & 22 & 14 & 28 & 21 & 20 & 10 & 24 \\
& $2 \mathrm{~b}$ & 16 & 20 & 16 & 22 & 18 & 24 & 15 & 16 \\
& 3 & 18 & 15 & 16 & 12 & 23 & 3 & 10 & 0 \\
\hline \multirow{5}{*}{ Abnormal } & $2 \mathrm{a}$ & 42 & 64 & 55 & 61 & 55 & 77 & 59 & 64 \\
& $2 \mathrm{~b}$ & 53 & 65 & 60 & 70 & 60 & 79 & 63 & 61 \\
& 3 & 54 & 48 & 43 & 54 & 60 & 68 & 54 & 56 \\
\hline
\end{tabular}




\section{Conclusions}

The values of SPI and SPEI at different temporal scales in the study area showed drought occurrence in several periods in 1997 and 2011 for all groups of stations in meddle and upper regions of the Sonora River basin. Droughts were identified in 1999 and 2000 in groups $2 \mathrm{a}$ and, $2 \mathrm{~b}$, while groups $1,2 \mathrm{~b}$ and 3 presented some moisture deficit in 2012 and 2013.

The linear fit estimated by regression of the temporal series showed a negative trend throughout the study period, indicating a clear increase in the intensity and frequency of drought events in the study area. The negative trend occurred between 1997 and 2013, coinciding with results reported by different authors and institutions.

The frequency of drought in group 3 was lower, attributed to higher precipitation in these areas associated with the interaction of the mountain systems that force air ascent from the Gulf of California, leading to increased condensation and precipitation development. In contrast, in group 2, located in the intermountain valleys where winds descend and inhibit cloud formation, precipitation decreases and there is greater occurrence of exceptional droughts.

Calculation and interpretation of SPI and SPEI at different temporal scales enables convincing detection of the most important drought events of some intensity. However, because it uses a climate balance (P-ETP), SPEI includes water demand by the atmosphere and reveals a more realistic panorama of water availability in the study zone than SPI, which is based solely on precipitation data. We recommend the use of the SPEI over the SPI, because it explicitly considers temperature and evapotranspiration.

The results obtained in this work are relevant and helpful in future water planning and management for all uses. Future research in this topic and in this area should be directed towards seasonal forecast of droughts to enable advance preparation to reduce and mitigate their effects.

\section{References}

Allen RG, Pereira LS, Raes D, Smith M. 2006. Evapotranspiración del cultivo: guías para la determinación de los requerimientos de agua de los cultivos. In Estudio FAO riego y drenaje (Vol. 298).
Begueria S, Vicente-Serrano SM. 2017. Calculation of Standardised Precipitation-Evapotranspiration index (1.7; Issue June). http://sac.csic.es/spei

Burton I, Kates RW, White GF. 1993. The environment as hazard (T. G. Press, Ed.; 2nd ed.).

Campos-Aranda DF. 1998. Procesos del ciclo hidrológico. Facultad de Ingeniería. Universidad de San Luis Potosí, 3rd ed.

Campos-Aranda DF. 2018. Quantification with SPEI of historical Droughts and under probable climatic change in the climatological station Zacatecas, Mexico. Tecnología y Ciencias del Agua 9: 210-233. https://doi. org/10.24850/j-tyca-2018-02-09

Castillo-Castillo M, Ibáñez-Castillo LA, Valdés JB, Arteaga-Ramírez R, Vázquez-Peña MA. 2017. Análisis de sequías meteorológicas en la cuenca del río Fuerte, México. Tecnología y Ciencias del Agua 8: 35-52. https://doi.org/10.24850/j-tyca-2017-01-03

CONABIO. 2020. Portal de Geoinformación 2020, Climatología, Isotermas Medias Anuales. http://www. conabio.gob.mx/informacion/gis

CONAGUA. 2010. Estudio de escasez de agua en la cuenca del rio Sonora. Organismo de Cuenca Noroeste, Hermosillo, Sonora. 58 p.

CONAGUA. 2013. Programa de Medidas Preventivas y de Mitigación a la Sequía (PMPMS) - Consejo de Cuenca Alto Noroeste. Comisión Nacional del Agua.

Cuadrat JM, Serrano R, Saz MA, Tejedor E, Prohom M, Cunillera J, Esteban P, Soubeyroux JM, Deaux N. 2013. Creación de una base de datos homogeneizada de temperaturas para los Pirineos (1950-2010). Geographicalia 63-64: 63-74. https://doi.org/10.26754/ ojs_geoph/geoph.201363-64854

Droogers P, Allen RG. 2002. Estimating reference evapotranspiration under inaccurate data conditions. Irrigation and Drainage Systems 16: 33-45. https:// doi.org/10.1023/A:1015508322413

Eakin H, Magaña V, Smith J, Moreno JL, Martínez JM, Landavazo O. 2007. A stakeholder driven process to reduce vulnerability to climate change in Hermosillo, Sonora, Mexico. Mitigation and Adaptation Strategies for Global Change 12: 935-955. https://doi. org/10.1007/s11027-007-9107-4

Esquivel-Arriaga G, Cerano-Paredes J, Sánchez-Cohen I, Velásquez-Valle MA, Flores-López F, Bueno-Hurtado P. 2019. Temporal analysis of droughts (19222016) in the upper Nazas River Basin using SPI and its relationship with ENSO. Tecnología y Ciencias 
Del Agua 10: 126-151. https://doi.org/10.24850/jtyca-2019-05-05

Estarelles R, De la Fuente EI, Olmedo P. 1992. Aplicación y valoración de diferentes algoritmos no-jerárquicos en el análisis cluster y su representación gráfica. Anuario de Psicología 55: 63-90.

Gómez JD, Etchevers JD, Monterroso AI, Gay C, Campo J, Martínez M. 2008. Spatial estimation of mean temperature and precipitation in areas of scarce meteorological information. Atmosfera 21: 35-56.

INEGI. 2015. Encuesta Intercensal de Población y Vivienda 2015. Instituto Nacional de Estadística y Geografía. http://cuentame.inegi.org.mx/monografias/informacion/son/poblacion

Khatiwada KR, Pandey VP. 2019. Characterization of hydro-meteorological drought in Nepal Himalaya: A case of Karnali River Basin. Weather and Climate Extremes 26: 100239. https://doi.org/10.1016/j. wace.2019.100239

Lobato-Sánchez R. 2016. El monitor de la sequía en México. Tecnología y Ciencias del Agua 7: 197-211.

Mallants D, Feyen J. 1990. Defining homogeneous precipitation regions by means of principal components analysis. Journal of Applied Meteorology 29: 892-901. https://doi.org/10.1175/1520-0450(1990)029<0892 :DHPRBM $>2.0 . \mathrm{CO} ; 2$

McKee TB, Doesken NJ, John K. 1993. The relationship of drought frequency and duration to time scales. Eighth Conference on Applied Climatology, American Meteorological Society, 179-184.

Mishra AK, Singh VP. 2010. A review of drought concepts. Journal of Hydrology 391: 202-216. https://doi. org/10.1016/j.jhydrol.2010.07.012

Navarro NLA, Moreno VJL. 2016. Cambios en el paisaje arbolado en Hermosillo: escasez de agua y plantas nativas. Región y Sociedad 28: 79-120.

OMM. 2011. Guía de prácticas climatológicas. Organización Meteorológica Mundial (Vol. 100). https:// library.wmo.int/doc_num.php?explnum_id $=10027$

OMM, Asociación Mundial para el Agua. 2016. Manual de indicadores e índices de sequía. Programa de gestión integrada de sequías, Serie 2 de herramientas y directrices para la gestión integrada de sequías. https:// www.droughtmanagement.info/literature/WMOGWP_Manual-de-indicadores_2016.pdf

Ortiz-Gómez R, Cardona-Diaz JC, Ortiz-Robles FA, Alvarado-Medellin P. 2018. Characterization of droughts by comparing three multiscale indices in Zacatecas,
Mexico. Tecnología y Ciencias del Agua 9: 47-91. https://doi.org/10.24850/j-tyca-2018-03-03

Paredes F, La Cruz F, Guevara E. 2014. Análisis regional de frecuencia de las sequías meteorológicas en la principal región cerealera de Venezuela. Bioagro 26 : 21-28.

Ponvert-Delisles B, Dámaso R. 2016. Algunas consideraciones sobre el comportamiento de la sequía agrícola en la agricultura de Cuba y el uso de imágenes por satélites en su evaluación. Cultivos Tropicales 37: 22-41. https://doi.org/10.13140/ RG.2.1.4591.3843

Ravelo AC, Sanz-Ramos R, Douriet Cárdenas JC. 2014. Detección, evaluación y pronóstico de las sequías en la región del Organismo de Cuenca Pacífico Norte, México. Agriscientia 31: 11-24.

Reynolds AP, Richards G, De la Iglesia B, Rayward-Smith VJ. 2006. Clustering rules: A comparison of partitioning and hierarchical clustering algorithms. Journal of Mathematical Modelling and Algorithms 5: 475-504. https://doi.org/10.1007/s10852-005-9022-1

RStudio Team. 2018. RStudio: Integrated Development Environment for R. RStudio, Inc. http://www.rstudio.com/

Serrano-Barrios L, Vicente-Serrano SM, Flores-Magdaleno H, Tijerina-Chávez L, Vázquez-Soto D. 2016. Variabilidad espacio-temporal de las sequías en la cuenca Pacífico Norte de México (1961-2010). Cuadernos de Investigación Geográfica 42: 185-204. https://doi. org/10.18172/cig.2857

SMN. (2019). Red de Estaciones Climatológicas. Climatología mensual. México, DF. Servicio Meteorológico Nacional. https://smn.conagua.gob.mx/tools/RESOURCES/Mensuales/son/00026139.TXT

Spinoni J, Barbosa P, De Jager A, McCormick N, Naumann G, Vogt JV, Magni D, Masante D, Mazzeschi M. 2019. A new global database of meteorological drought events from 1951 to 2016. Journal of Hydrology: Regional Studies 22: 100593. https://doi.org/10.1016/j. ejrh.2019.100593

Sthale DW, Cook ER, Villanueva DJ, Fye FK, Burnette DJ, Griffin RD, Acuña SR, Seager R, Heim JRR. 2009. Early 21 st- Century Drought in Mexico. EOS Transactions, 90: 89-90. https://doi.org/10.1029/2009EO110001

UNCCD. (1994). United Nations Convention to combat desertification in countries experiencing serious drought and/or desertification, particularly in Africa. In United Nations Convention to Combat Desertification. https://wedocs.unep.org/handle/20.500.11822/27569 
Urrutia JA, Lemus RP. 2010. Componentes principales en la determinación de estaciones con patrones homogéneos de temperatura en El Chocó. Scientia et Technica 2: $257-262$.

Valiente OM. 2001. Sequía: definiciones, tipologías y métodos de cuantificación. Investigaciones Geográficas 26: 59-80. https://doi.org/10.14198/ INGEO2001.26.06

Velasco I, Aparicio J, Valdés JB, Velázquez J, Kim T. 2004. Evaluación de índices de sequía en las cuencas de afluentes del río Bravo/Grande. Ingeniería Hidráulica en México 19: 37-53.

Vicario L, García CM, Teich I, Bertoni JC, Ravelo A, Rodríguez A. 2015. Caracterización de las sequías meteorológicas en la región central de la Argentina. Tecnología y Ciencias del Agua 6: 153-165.

Vicente-Serrano SM, Beguería S, Lorenzo-Lacruz J, Camarero JJ, López-Moreno JI, Azorín-Molina C, Revuelto J, Morán-Tejeda E, Sánchez-Lorenzo A. 2012. Análisis comparativo de diferentes índices de sequía para aplicaciones ecológicas, agrícolas e hidrológicas. 8o Congreso Internacional de La Asociación Española de Climatología (pp 679-689).

Vicente-Serrano SM, Beguería S, López-Moreno JI. 2010. A multiscalar drought index sensitive to global warming: The standardized precipitation evapotranspiration index. Journal of Climate 23: 1696-1718. https://doi. org/10.1175/2009JCLI2909.1

Wilhite DA, Glantz MH. 1985. Understanding the drought phenomenon: The role of definitions. Water International 10: 111-120. https://doi.org/10.1080/02508068 508686328

Zarch MAA, Malekinezhad H, Mobin MH, Dastorani MT, Kousari MR. 2011. Drought Monitoring by Reconnaissance Drought Index (RDI) in Iran. Water Resources Management 25: 3485-3504. https://doi.org/10.1007/ s11269-011-9867-1

Zargar A, Sadiq R, Naser B, Khan FI. 2011. A review of drought indices. Environmental Reviews 19: 333-349. https://doi.org/10.1139/a11-013 